\title{
Computerised tomography findings in lymphobronchial tuberculosis: A comparison between infants and older children
}

\begin{tabular}{|c|c|}
\hline \multicolumn{2}{|c|}{$\begin{array}{l}\text { Authors: } \\
\text { Heleen Hanekom }^{1} \text { (D) } \\
\text { Susan Lucas }{ }^{1} \text { (D) } \\
\text { Savvas Andronikou }^{2} \\
\text { Pierre Goussard }^{3} \\
\text { Robert P. Gie }^{3} \text { (D) }\end{array}$} \\
\hline \multicolumn{2}{|c|}{$\begin{array}{l}\text { Affiliations: } \\
{ }^{1} \text { Department of Radiology, } \\
\text { University of the } \\
\text { Witwatersrand, South Africa }\end{array}$} \\
\hline \multicolumn{2}{|c|}{$\begin{array}{l}{ }^{2} \text { Department of Paediatric } \\
\text { Radiology, Bristol Royal } \\
\text { Hospital for Children, } \\
\text { University of Bristol, } \\
\text { United Kingdom }\end{array}$} \\
\hline \multicolumn{2}{|c|}{$\begin{array}{l}{ }^{3} \text { Department of Paediatrics } \\
\text { and Child Health, } \\
\text { Stellenbosch University, } \\
\text { South Africa }\end{array}$} \\
\hline \multicolumn{2}{|c|}{$\begin{array}{l}\text { Corresponding author: } \\
\text { Heleen Hanekom, } \\
\text { heleen.hanekom@yahoo. } \\
\text { co.za }\end{array}$} \\
\hline \multicolumn{2}{|c|}{$\begin{array}{l}\text { How to cite this article: } \\
\text { Hanekom H, Lucas S, } \\
\text { Andronikou S, Goussard P, } \\
\text { Gie RP. Computerised } \\
\text { tomography findings in } \\
\text { lymphobronchial } \\
\text { tuberculosis: A comparison } \\
\text { between infants and older } \\
\text { children. S Afr J Rad. } \\
\text { 2017;21(1), a1149. https:// } \\
\text { doi.org/10.4102/sajr. } \\
\text { v21i1.1149 }\end{array}$} \\
\hline \multicolumn{2}{|c|}{$\begin{array}{l}\text { Copyright: } \\
\text { (C) 2017. The Authors. } \\
\text { Licensee: AOSIS. This wo } \\
\text { is licensed under the } \\
\text { Creative Commons } \\
\text { Attribution License. }\end{array}$} \\
\hline \multicolumn{2}{|l|}{ Read online: } \\
\hline 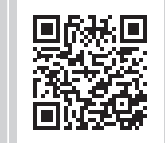 & $\begin{array}{l}\text { Scan this QR } \\
\text { code with your } \\
\text { smart phone or } \\
\text { mobile device } \\
\text { to read online. }\end{array}$ \\
\hline
\end{tabular}

Background: Pulmonary tuberculosis (TB) in children is characterised by mediastinal and hilar lymphadenopathy. Lymphobronchial TB (LBTB) describes the situation where tuberculous lymph nodes affect the airways by compression or erosion. Infants may be more susceptible to severe complications because of their specific airway anatomy and immature immune systems.

Objective: The purpose of this study was to compare the computerised tomography (CT) findings of infants and children older than 12 months with LBTB to determine whether infants are more severely affected.

Materials and methods: The CT scan reports of 98 children ( $<13$ years) with LBTB were reviewed retrospectively by a paediatric radiologist for a previous study. The relevant data were extracted from the existing database and the two age groups were compared with regard tolymphadenopathy, airway narrowing and parenchymal complications.

Results: Of the 98 patients, 51\% were infants. There was no statistically significant difference between infants and children (> 12 months) with reference to the frequency and distribution of airway compressions, lymphadenopathy and parenchymal findings. However, there was a statistically significant difference $(p<0.05)$ in the number of infants with complete compressions when compared to the older children.

Conclusion: As opposed to older children, infants' airways are more susceptible to complete airway compression as a result of LBTB. This is probably because of the airway size and anatomic development. We therefore recommend that infants presenting with symptoms of airway compression secondary to LBTB should be imaged urgently using CT scanning to ensure correct management.

Note: A selection of conference abstracts: RSSA/SASPI Paediatric Imaging Congress, 03-06 November 2016, Spier Estate, Stellenbosch, South Africa. Faculty collaborators: Professor Kassa Darge (Body Imaging, University of Pennsylvania, Philadelphia, USA), Professor Edward Lee (Thoracic Imaging, Harvard University, USA), Professor Beverley Newman (Cardiac Imaging, Stanford University, California, USA), Professor Kimberly Applegate (Image Gently and Body Imaging, Emory University, Atlanta, USA) and Professor Savvas Andronikou (Thoracic Imaging, University of Bristol, UK) supported by South African Paediatric Radiologists, co-ordinated by Dr Jaishree Naidoo, President of the African Society of Paediatric Imaging and Head of Division of Paediatric Radiology, Charlotte Maxeke Johannesburg Academic Hospital.

This conference abstract is partially based on the following publication: Hanekom $H$, Lucas S, Andronikou S, Gie R, Goussard P. Computerised tomography findings in lymphobronchial tuberculosis: A comparison between infants and older children. South Afr J Infect Dis 2015;30(1), 63-64, available here: http://www.sajei.co.za/index.php/SAJE/article/download/704/862 